\title{
PENERAPAN MODEL FLEX BLENDED LEARNING PADA SISTEM PENDIDIKAN JARAK JAUH
}

\author{
Penulis \\ : Yuliani \\ Institusi \\ : Magister Teknologi Pendidikan, Universitas Muhammadiyah Jakarta \\ Email Korespondensi \\ : yulianiadeg08@gmail.com \\ DOI \\ $10.53947 /$ perspekt.v1i2.18
}

\begin{abstract}
Abstrak
Memasuki era 4.0, segala sektor dalam aktivitas kehidupan sudah mulai terdigitalisasi, begitupun yang terjadi dalam sektor pendidikan. Selain itu kondisi Pandemi COVID-19 mewajibkan aktivitas pembelajaran dilakukan di rumah. Hal tersebut tentunya menuntut peran teknologi digital untuk mendukung sistem pendidikan jarak jauh atau yang lebih dikenal PJJ. Namun dalam penerepan sistem pendidikan jarak jauh tentunya tidak mudah dan banyak hal yang menjadi kendala-kendala dalam sistem pembelajaran tersebut, hal ini disebabkan beberapa hal antara lain kesiapan guru dan siswa menghadapi proses pembelajaran yang berbeda dari sebelumnya dan juga model dari desain pembelajaran yang tentunya perlu di sesuaikan agar hasil dari pembelajaran dapat tetap maksimal. Tentunya banyak alternatif model pembelajaran dalam sistem pembelajaran jarak jauh, salah satu yang dapat diterapkan pada situasi saat ini ialah Model Flex blanded learning.
\end{abstract}

\section{Abstract}

Entering the 4.0 era, all sectors in life activities have begun to be digitized, as has happened in the education sector. In addition, the COVID-19 pandemic condition requires learning activities to be carried out at home. This of course

Keywords: demands the role of digital technology to support the distance education system or better known as PJJ. However, in implementing the distance education system, it is certainly not easy and many things become obstacles in the learning system, this is due to several things, including the readiness of teachers and students to face a different learning process than before and also the model of learning design which of course needs to be implemented. adjusted so that the results of learning can remain maximal. Of course, there are many alternative learning models in distance learning systems, one of which can be applied to the current situation is the Flex blended learning model.

Blended learning

Flex Model

Learning model

Education technology

\section{PENDAHULUAN}

Pendidikan di era saat ini tentunya sangat berbeda dengan pendidikan pada era sebelumnya, salah satu yang sangat terlihat dari perbedaan tersebut ialah bagaimana pendidikan saat ini memaksimal peran teknologi digital dalam proses belajar mengajar, sesederhana menggunakan aplikasi e-learning.
Digital sendiri secara etimologi berarti jari jemari yang secara istilah dapat diartikan sebagai sebuah sistem teknologi yang sudah berlandaskan komputerisasi. Melalui sistem komputerasasi tentunya siswa mendapatkan kemudahan dalam mengakses sebuah pembelajaran bahkan mendapatkan ilmu dari berbagai sumber yang berlimpah ruah, namun kemampuan siswa dan guru juga tentunya perlu ditingkatkan dalam 
memanfaatkan teknologi digital agar mempermudah proses belajar mengajar, jangan sampai kegaptekan membuat proses belajar mengajar yang harusnya lebih efektif dan efisien menjadi sebaliknya dikarenakan faktor tersebut.

Selanjutnya kondisi pandemi yang saat ini terjadi di Indonesia belum menemukan titik terang penyelesaian, sejak pasien pertama COVID-19 ditetapkan pada tanggal 14 Februari 2020, kasus terus berkembang hingga hari ini, sudah beberapa kali kebijakan pemerintah dalam upaya menurunkan kasus COVID-19 di NKRI, bermula dari diberlakukannya kebijakan Pembatasan Sosial Berskala Besar (PSBB), Pelarangan Mudik sampai Pemberlakuan Pembatasan Kegiatan Masyarakat (PPKM) telah diterapkan namun tingkat penyebaran covid masih tingi bahkan hingga saat ini beberapa varian dari COVID-19 yang berasal dari luar negeri sudah masuk di Indonesia yang antara lain adalah Varian Alpha, Varian Alpha dari COVID-19 awal mulanya dijumpai di Negara Inggris tepatnya di Bulan September 2020

Varian Alpha dari virus COVID-19 memungkinkan manusia untuk mereproduksi dan mereplikasi diri sebagai inang. Karena hilangnya 69 dan 70 gen virus ini, penyebarannya lebih cepat dari virus aslinya. Halaman ilmuwan baru menulis bahwa varian Alpha dari COVID-19 memiliki tingkat penularan 1,5 kali lipat dari virus COVID-19 sebelumnya, dan risiko kematian 1,6 kali lipat dari yang sebelumnya. Gejala varian COVID-19 Alpha tidak jauh berbeda dengan gejala sebelumnya, seperti batuk dan demam terusmenerus.

Beberapa pasien varian Alpha dari COVID-19 kehilangan indra penciumannya. Selanjutnya setelah tiga bulan setelah ditemukannya varian Alpha, virus COVID19 kembali bermutasi menjadi strain baru. Kali ini mutasi tersebut pertama kali terdeteksi dalam jumlah besar di Afrika Selatan pada Desember 2020. Varian baru ini memiliki mutasi N501, dinamakan varian Beta COVID-19, dan dianggap lebih menular dibandingkan varian Alpha. Karena penyebarannya yang luar biasa cepat, varian Beta dari COVID-19 ini memicu gelombang kedua pandemi di Afrika Selatan. Pasien dengan varian Beta COVID-19 memiliki gejala yang lebih banyak daripada Alpha, seperti kehilangan penciuman, sakit kepala, sakit perut, sakit tenggorokan, batuk, suara serak, kelelahan, dan sesak napas. kulit. Selain itu, ia mengalami nyeri otot, nyeri dada dan diare.

Varian selanjutnya ialah Varian Delta COVID-19, jenis Varian Delta awal mulanya dijumpai di Negara Indonesia tepatnya pada Bulan Oktober 2020. Dalam perkembangan selanjutnya, Organisasi Kesehatan Dunia (WHO) kini menyatakan bahwa Varian Delta adalah strain utama COVID-19 di berbagai belahan dunia. Bukan hanya itu, Badan Litbang Kementerian Kesehatan RI juga merilis data pada Juni 2021 yang menunjukkan total 160 kasus varian Delta di 9 provinsi di Indonesia. Berbeda dengan varian Alpha, kecepatan transmisi varian Delta $60 \%$ lebih cepat, bahkan dapat ditransmisikan dalam waktu singkat tanpa memakai masker 
selama 5-15 detik interaksi. Gejala pada pasien COVID-19 varian Delta antara lain demam, sakit kepala, sakit perut, kehilangan nafsu makan, muntah, nyeri sendi, sakit tenggorokan, dan hidung meler/tersumbat.

Terakhir dari varian covid yang saat ini mewabah di Indonesia ialah varian kappa, Seperti varian Delta yang ditemukan di India, varian Kappa COVID-19 juga berasal dari India dan tiba di Indonesia pada 14 Januari 2021. Varian Kappa ini mirip dengan Delta, menyebar dengan cepat dan berpotensi mematikan. Gejala COVID-19 varian Kappa antara lain, pilek ruam kulit, batuk, demam yang tinggi, serta mata merah dan berair di sekujur tubuh. Varian Kappa COVID-19 ini merupakan strain virus yang menarik perhatian banyak pakar kesehatan. Menurut Guardian, Raina Macintyre, direktur proyek penelitian keamanan hayati Institut Kirby, mengatakan bahwa varian Kappa memiliki kecenderungan untuk mengurangi efektivitas vaksin COVID-19 tertentu. "Ada juga bukti tertulis dari India bahwa (varian COVID-19) strain Kappa dan Delta dan varian lainnya mungkin memiliki manifestasi klinis yang sedikit berbeda, seperti sakit perut, diare, dan gejala gastrointestinal," kata Raina Macintyre.

\section{PEMBAHASAN}

Segala bentuk varian COVID-19 tersebut tentunya akan membuat kekhawatiran pemerintah untuk melakukan kegiatan pembelajaran secara langsung di sekolah dan tentunya berdampak kepada keputusan untuk meneruskan program pendidikan jarak jauh. Hal tersebut tentunya menjadi sebuah tantangan bagi seluruh komponen belajar baik siswa dan juga guru. Dalam hal tersebut di rasa perlu adanya suatu model pembelajaran yang sesuai dengan kondisi terkini, oleh karena itu perlu dibuat kajian secara literatur mengenai model pembelajaran yang sesuai dengan sistem pendidikan jarak jauh.

Salah satu model pembelajaran yang tepat di masa pandemi saat ini yang mengharuskan pelajar belajar secara daring yaitu Model Blended learning. Model Blended learning, Menurut Catlin R. Tucker dalam Blended learning secara universal terdapat 6 model (Tucker, 2012), ialah:

\section{Face- To- Face Driver Model}

Mengaitkan peserta bukan hanya melakukan kegiatan belajar di dalam kelas ataupun laboratorium, namun juga terkait dengan kegiatan peserta didik yang dilakukan di luar kelas dengan dukungan perangkat teknologi secara daring.

\section{Rotation Model}

Model ini mengkombinasikan modul pembelajaran secara daring sembari tetap melakukan kegiatan pembelajaran di dalam ruang kelas dalam pengawasan pendidik.

\section{Flex Model}

Menggunakan perangkat internet dalam menyampaikan materi pendidikan kepada partisipan/siswa. Dalam perihal ini partisipan bisa membuat grup dialog.

\section{Online Lap Model}

Kegiatan belajar mengajar dilakukan dalam kelas komputer dengan seluruh modul pendidikan disajikan tidak perlu menggunakan file yang di print cukup soft file, dan peserta didik berhubungan dengan guru secara online. Dalam perihal ini 
pendidik didampingi oleh pengawas supaya kedisiplinan serta ketertiban dalam kegiatan pembelajaran senantiasa terpelihara.

\section{Self Blend Model}

Dalam model ini partisipan menghadiri kegiatan pembelajaran secara daring, dan segala kegiatan di dalam kelas dapat di kerjakan di luar kelas.

\section{Online Driver Model}

Ialah pendidikan melalui media daring, dalam model ini pendidik dapat memasukkan materi pengajaran di media internet, sehingga partisipan bisa mendownload dimanapun mereka berada supaya partisipan nantinya partisipan dalam melakukan kegiatan belajar mandiri di luar kelas yang selanjutnya akan dilakukan kegiatan pembelajaran tatap muka dengan kesepakatan antara siswa satu sama lain.

Dari beragam model dari blended learning peneliti mencoba satu diantara banyak model yang di rasa paling tepat dalam penerapan di masa pandemi COVID-19 saat ini. Maka dari itu peneliti memilih flex model sebagai salah satu model yang akan peneliti kaji secara literatur agar tujuan pembelajaran secara daring dapat terwujud dengan efektif dan juga efisien.

\section{Pendidikan Jarak Jauh}

Menurut Hidayat dkk. Pendidikan jarak jauh merupakan sistem pembelajaran yang dilakukan pada dasarnya tidak secara tatap muka ataupun tidak dilaksanakan di dalam kelas, titik proses pembelajaran ini biasanya dilakukan dengan menggunakan bantuan media sebagai penunjang titik misalnya seperti internet, siaran radio, aplikasi telepon, televisi, komputer, maupun berbagai bentuk media cetak atau modul (Hidayat dkk., 2021). Senada dengan Hidayat dkk., Damayanti menyatakan bahwa pembelajaran daring atau pembelajaran jarak jauh merupakan pembelajaran yang dalam pelaksanaannya menggunakan akses internet serta menggunakan alat bantu seperti komputer atau gadget yang dapat menunjang proses pembelajaran jarak jauh (Damayanti, 2019). Lebih lanjut Suradika dkk. menyatakan bahwa tujuan dari pembelajaran Jarak Jauh adalah untuk tetap memenuhi standar pendidikan melalui pemanfaatan teknologi berupa perangkat komputer atau gawai yang menghubungkan guru dengan peserta didik sehingga pembelajaran tetap terlaksana meskipun tidak ada kesatuan ruang dan waktu (Suradika dkk., 2020).

Selain itu Pendidikan Jarak Jauh (PJJ) di dalam dunia pendidikan ini telah memiliki regulasi yaitu pada Undang - Undang RI No. 20 Tahun 2003 yang berbicara mengenai Sistem Pendidikan Nasional (Sisdiknas) di bagian kesepuluh tentang Pendidikan Jarak Jauh pasal 31, berbunyi: (1) Pendidikan jarak jauh dapat diselenggarakan pada semua jalur, jenjang, dan jenis pendidikan. (2) Pendidikan jarak jauh berfungsi memberikan layanan kepada kelompok masyarakat yang tidak dapat mengikuti pendidikan secara tatap muka atau regular. (3) Pendidikan jarak jauh diselenggarakan dalam berbagai bentuk, modus, dan cakupan yang didukung oleh sarana dan layanan belajar serta sistem penilaian yang menjamin mutu lulusan sesuai dengan standar nasional pendidikan. (4) Ketentuan mengenai penyelenggaraan pendidikan jarak jauh sebagaimana dimaksud dalam ayat (1), ayat (2), dan ayat (3) diatur 
lebih lanjut dengan Peraturan Pemerintah (Undang-Undang Indonesia Nomor 20 Tahun 2003 Tentang Sistem Pendidikan Nasional, 2003).

Karakteristik khas utama PJJ ialah: 1) terdapatnya jarak yang jauh antara pendidik dengan partisipan didik, 2) indivisualisasi serta kemandirian dalam belajar. Tidak hanya itu terdapat sebagian ciri lain yang jadi karakteristik khas PJJ, ialah: 3) terdapatnya bahan belajar yang umumnya dibesarkan sendiri oleh lembaga penyelenggara PJJ, 4) pemakaian bermacam media pendidikan, 5) terdapatnya dorongan belajar yang berbentuk bimbingan serta dorongan belajar yang lain yang terbatas, 6) terdapatnya proses industrialisasi dalam pengembangan, pengadaan, serta distribusi bahan belajar. Dengan demikian dalam proses pendidikannya (Warsita, 2007).

\section{Blended Learning}

Pada keadaan di saat ini, tepatnya di kala Pandemi COVID-19 yang mewajibkan kita melaksanakan aktivitas belajar mengajar secara daring, pastinya kita sangat memerlukan kemudahan dalam melakukan aktivitas tersebut serta salah satu model pendidikan yang pastinya bisa menunjang aktivitas belajar mengajar secara daring yakni Model Blended learning (Warsita, 2007).

Menurut Bersin Menggambarkan sejarah Blended learning yang tumbuh di dunia pelatihan pada awal mulanya dicoba pada lembaga pembelajaran ialah sumber belajar utama merupakan pelatih/ fasilitator. Dengan ditemuinya teknologi PC, pelatihan dilakukam memakai mainframe based yang bisa melaksanakan aktivitas pelatihan secara individual tidak tergantung pada waktu serta modul yang sama (tidak sinkron). Pertumbuhan selanjutnya pendidikan yang senantiasa memakai basis pc namun energi jangkaunya jadi lebih lugas melintasi pulau serta daratan sebab pertumbuhan teknologi satelit. Demikian pula, isi pelatihan dicoba penyebarannya lewat CD ROM serta internet. Dikala ini pelatihan mencampurkan seluruh itu supaya pendidikan jadi lebih efisien, efektif dengan, konsep campuran (blended) (Bersin, 2010).

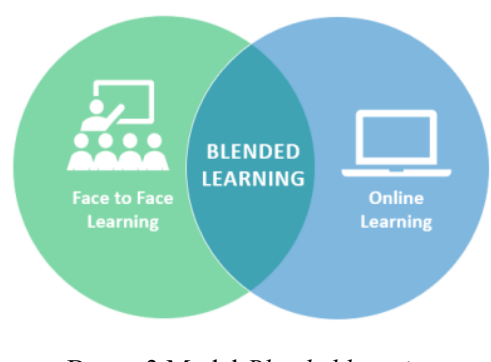

Bagan 3 Model Blended learning

Menurut Syarif Melalui model Blended learning, proses pendidikan akan lebih efisien disebabkan kegiatan pendidikan yang biasa digunakan secara umum/tradisional nantinya akan didukung dengan pendidikan yang menggunakan perangkat internet yang tentunya berdasarkan infrastruktur teknologi data serta dapat dicoba kapanpun serta dimanapun (Syarif, 2013).

Sebagian teori di atas yang terkait dengan Model Blended learning menampilkan efektitifitas dari model tersebut disebabkan sudah melalui bermacam pengembangan dalam pendidikan daring sehingga Model Blended learning terus menjadi efisien dalam penggunaannya pada sistem pendidikan. Walaupun pastinya pelaksanaannya tidak gampang.

Mempraktikkan Blended learning tentunya bukan masalah yang gampang 
disebabkan perlunya persiapan mendasar mulai dari kedudukan pendidik-peserta didik, perancangan konten serta infrastruktur (Rachmah, 2019). Ada pula Syarat- syarat dasar dalam mempraktikkan Blended learning antara lain:

1) Pendidik yang mumpuni, walaupun peserta didik menjadi pusat dari model pendidikan blended, namun pendidik senantiasa memiliki peran yang sangat berarti. Pendidik yang telah matang dalam dunia pendidikan blended nantinya akan semakin ahli dan juga terampil dalam upaya menyatupadukan kedua tradisi yang berbeda antara model klasik dengan teknologi. Pendidik wajib dilatih dalam meningkatkan konten dalam tampilan digital, pengalaman dalam menjelajahi internet, mengenali website-website yang bermanfaat dalam proses pendidikan dan sanggup menggunakan web, Skype, Google Talk buat melaksanakan video conference.

2) Memiliki perilaku ilmiah, tenaga pengajar wajib mempunyai perilaku ilmiah yang bagus agar nantinya memiliki keahlian saintifik yang sama dengan prilaku ilmiahnya. Pendidik wajib memiliki kemampuan dalam mengamati hingga pemecaham permasalahan. Perilaku ilmiah bisa menolong pendidik dalam mengalami kegagalan dan sanggup menganalisi keadaan secara positif jika seandainya Blended learning tidak sanggup berjalan secara maksimal.

3) Memiliki sudut pandang yang luas serta prilaku dan menanggapi sebagai hal yang positif setiap bentuk pergantian

4) Sarana yang lengkap semacam laboratorium pc, koneksi internet serta platform untuk membuat Blended learning. Keberhasilan Blended learning bergantung dari sarana yang baik disebabkan hal tersebut menjadi yang utama dalam Blended learning

5) Partisipan memiliki akses internet.

6) Menjalankan sistem dengan cara yang flexibel,

7) Orang tua dari peserta didik harus bersama-sama sepakat dengan penggunaan Blended learning. Kebanyak dari setiap orang tua yang masih terkungkung dengan pendidikan tradisional serta menyangkal Blended learning karena menurut mereka blended learning ialah" hanya membuang waktu tenaga dengan percuma. Bagi orang tua yang menyadari melalui pendekatan inovatif bisa menerima realitas kalau Blended learning bisa berguna bagi putra - putri mereka.

8) Penilaian dapat dilaksanakan secara berkepanjangan serta fleksibel. Evaluasi internal berkepanjangan serta uji formatif merupakan bentuk pengujian yang bisa dicoba dalam Blended learning. Penilianpun dapat dilakukan secara daring yang menyebabkan sistem dapat terlihat lebih fleksibel.

Berikutnya dalam melakukan pembelajran dengan memakai Blended learning pastinya terdapat kunci tertentu yang wajib dikenal, Bagi Carman, terdapat 5 kunci agar dapat melakukan pendidikan dengan memakai Blended learning (Carman, 2002), yaitu:

1) Live Event, pendidikan langsung ataupun tatap muka secara sinkronous dalam waktu serta tempat yang sama maupun waktu sama tetapi tempat berbeda.

2) Self- Paced Learning, ialah mengombinasikan dengan pendidikan mandiri (self-paced learning) yang membolehkan partisipan belajar kapan saja, dimana saja secara online.

3) Collaboration, mengombinasikan kerja sama, baik kerjasama pengajar, ataupun kerjasama antar partisipan belajar.

4) Assessment, perancang wajib sanggup meramu campuran tipe asesmen online serta offline baik yang bertabiat uji ataupun non- tes.

5) Performance Support Materials, yakinkan bahan belajar disiapkan dalam wujud digital, bisa diakses oleh partisipan belajar baik secara offline ataupun online. 
Menurut Bakhrul Model pendidikan Blended learning ini memusatkan pada pendidikan mandiri kepada partisipan didik lewat online learning. Jadi pengajar sudah memastikan fokus- fokus pendidikan beserta haluan - haluan pendidikan buat dilaksanakan partisipan didik, dikala mereka melaksanakan pendidikan daring. Pengajar dalam model Blended learning ini cuma selaku fasilitator serta terkadang dapat memakai tatap muka apabila diperlukan (Amal, 2019).

Teori tersebut menegaskan fungsi guru yang tidak lagi sekedar pemberi materi namun lebih berperan sebagai fasilitator yang mendampingi siswa dalam kegiatan belajar mengajar. Hal tersebut tentunya dapat meningkatkan kreativitas dan inovasi dari siswa dikarenakan mereka tidak hanya menjadi objek yang terus menerima ilmu dan menyelesaikan soal-soal yang bersumber dari buku namun siswa juga bisa mejadi subjek dalam pembelajaran bahkan bisa berbagi wawasan dan gagasan tidak hanya ke sesama siswa namun juga kepada pendidik.

Selanjutnya di model flex ini yang tentunya memaksimalkan peran teknologi kedepannya akan mempemudah akses ilmu pengetahuan yang tidak terbatas dan tentunya akan bermanfaat bagi percepatan kemajuan dalam dunia pendidikan karena peserta didik tidak hanya mendapatkan sumber pengetahuan dari buku.

\section{Model Flex Blended Learning}

Sebelum membahas lebih jauh mengenai Flex blended learning baiknya kita mulai dengan mengetahui apa yang dimaksud dengan Flex blended learning . Flex blended learning ialah salah satu jenis dari model pembelajaran Blended learning yaitu pembelajaran yang sepenuhnya dilakukan secara online / daring.

Blended learning Flex Model memusatkan pada pendidikan mandiri berbasis online learning dimana pengajar telah mempersiapkan fokus materi serta tugas lewat jaringan internet. Model pendidikan tidak bisa berjalan optimal tanpa pemakaian media yang maksimal (Ariawan dkk., 2021).

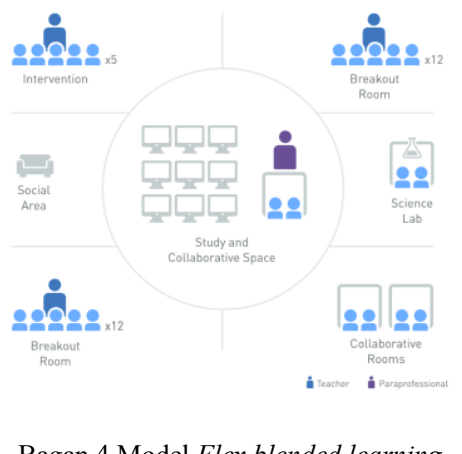

Dalam kelas Flex blended learning atau yang lebih dikenal dengan Flex kelas, tentunya juga harus dimulai dengan perencanaan serta persiapan yang matang apalagi bagi yang selama ini melakukan kegiatan belajar mengajar hanya secara offline atau tatap muka di kelas secara langsung. Oleh karena itu beberapa variabel harus menjadi perhatian antara lain : kesediaan jaringan, kesiapan materi pembelajaran secara daring serta berbagai variabel lain yang tentunya bisa menghambat proses belajar mengajar. Selanjutnya Setidaknya ada dua jenis Model Flex yang kan peneliti bahas yaitu jenis Sinkron dan Asinkron.

\section{- JENIS FLEX MODEL SINKRON DAN ASINKRON TIPE FLEX MODEL SINKRON}

Sinkron ataupun synchronous ialah pendidikan daring yang dilaksanakan secara 
realtime ataupun langsung. Pendidikan ini membolehkan pendidik menyampaikan isi modul pembelajaran secara realtimel langsung dan membolehkan pendidik serta pula partisipan didik berbicara secara realtime dalam aktivitas dialog ataupun tanya jawab. Keuatamaan dari pendidikan sinkron ini adalah model ini menghindarkan siswa dari perasaan terisolasi ataupun merasa tidak dicermati sebab terdapatnya interaksi antara pendidik serta partisipan didik lain sepanjang proses belajar.

Tetapi, kekurangan dari pendidikan sinkron ini yakni, aktivitas pendidikan jadi tidak begitu fleksibel paling utama dalam perihal waktu sebab pendidik serta partisipan didik wajib menjadwalkan waktu untuk menghadiri kegiatan pengajaran langsung pada waktu yang bertepatan sehingga bisa jadi tidak sempurna untuk mereka yang telah memiliki jadwal yang sudah padat. Ada pula sebagian contoh pemakaian pendidikan sinkron antara lain: dengan menggunakan Webmeeting dengan berbagai macam aplikasi antara lain Google Meet, Zoom, WebEx Meeting Center ataupun mengadakan tanya jawab serta dialog secara langsung pada aplikasi percakapan/ chat semacam: Whatsapp, Line serta media sosial semacam Facebook chat serta lain sebagainya.

\section{TIPE FLEX MODEL ASINKRON.}

Berikutnya Tipe Pendidikan asinkron ataupun asynchronous tipe tersebut merupakan pendidikan daring yang dilaksanakan secara tidak langsung. Pendidikan ini membolehkan seseorang guru mempersiapkan lebih dini modul pendidikan serta pendidik tidak perlu hadir secara realtime dikala berlangsungnya kegiatan pendidikan. Modul pendidikan serta komunikasi dengan siswa bisa diinformasikan lewat email ataupun pesan yang diposting di forum dialog tetapi pastinya pendidik tidak bisa secara langsung merespon tanggapan dari partisipan didik.

Dalam pendidikan asinkron ini, partisipan didik umumnya bisa menyelesaikan mata pelajaran mereka secara mandiri serta lebih fleksibel tanpa khawatir mengganggu waktu yang telah terjadwal serta bisa dikumpul dimanapun serta kapanpun.

Tetapi untuk partisipan didik yang kurang mempunyai motivasi dalam menyelesaikan tugasnya dapat jadi hal yang menyebabkan mereka merasa terisolasi disebabkan area yang interaktif tidak mereka temukan. Salah satu contoh pemakaian pendidikan asinkron ialah pemanfaatan aplikasi aplikasi sistem manajemen pendidikan (Learning Management SystemLMS) antara lain: Moodle, Google Classroom, Schoology, Edmodo serta lain sebagainya. Lewat platform ini, guru bisa mengunggah konten serta modul belajar, mengunggah media pendidikan (Power point ataupun Flash), aktivitas dialog online, kuis, serta melaksanakan penilaian ataupun evaluasi serta lain sebagainya.

Dengan diterapkannya Model Kelas Flex secara Sinkron serta Asinkron sangat diharapkan bisa membagikan pemecahan terhadap kasus pendidikan yang diterapkan secara daring supaya mampu mewujudkan pembelajaranan yang inovatif, kreatif, menarik serta pastinya efisien serta efektif yang hasilnya bisa tingkatkan hasil belajar partisipan didik. 


\section{KESIMPULAN}

Berdasarkan hasil kajian literatur mengenai Flex model maka penulis dapat menyimpulkan beberapa hal yaitu: Penggunaan Flex model bisa lebih efektif jika digunakan secara sinkron dan asinkron agar peserta bisa tetap terevaluasi segala tugas / materi yang telah diberikan. Karena dengan cara sinkron guru dan siswa dapat bertatap muka di dalam kelas virtual sebagai pengganti pertemuan di dalam kelas offline dan pada saat pertemuan realtime tersebut tentunya guru dapat mengevaluasi tugas yang telah diberikan kepada siswa secara online. Selanjutnya cara asinkron dapat meningkatkan rasa tanggung jawab terhadap tugas yang diberikan oleh guru melaui elearning dan juga bisa diakses kapanpun dan dimanapun tanpa harus bertemu langsung dengan guru tersebut.

Flex model ini ialah model yang menurut peneliti paling efektif saat ini karena tidak hanya mendesain pembelajaran secara realtime namun juga mendesain pembelajaran secara tidak langsung dengan memberi materi kepada siswa sebelum pembelajaran dimulai dan juga dapat mengirimkan tugas kepada siswa melalui email atau google classroom dan semacamnya

Dalam Flex model peran guru tidak hanya sebagai pengajar namun juga berperan sebagai fasilitator yang bertugas mendampingi siswanya, apalagi di masa pandemi yang segala aktivitas pendidikan dilakukan siswa di rumah tentunya dapat menimbulkan rasa jenuh dan jika tidak di dampingi maka tugas-tugas siswa dapat terbengkalai belum lagi jika memang pada dasarnya siswa tersebut termasuk kategori malas yang jika tidak di ingatkan maka sering terlupakan mengerjakan tugas.

\section{Masukan}

Dalam penerapan model Flex yang $100 \%$ dilakukan secara daring tentunya kesuksesan dalam belajar mengajar tidak hanya datang dari peran murid dan juga guru, namun peran orang tua sebagai pihak ketiga yang juga harus berkaitan sehingga dapat mencapai kesuksesan dalam penerapan model ini. Karena mau tidak mau waktu bersama orang tua di rumah lebih banyak ketimbang bersama guru di sekolah, apalagi saat ini pembelajarannya secara daring.

Di Indonesia sendiri yang sebaran jaringan internetnya belum merata di semua wilayah tentunya model Flex sangat susah diterapkan terutama di wilayah 3T (Terluar, Terpencil, Terdalam). Oleh karena itu untuk pertemuan secara realtime harus dilakukan dalam ruangan kelas namun tetap taat protokol kesehatan, begitu juga dengan pemberian tugas yang dilakukan secara online namun jika jaringan di daerah tersebut sudah tersedia tetapi masih lemah pemberian tugas bisa diberikan melalui aplikasi medsos seperti whatsapp, karena tidak terlalu membutuhkan sinyal internet yang kuat untuk berbagi tugas secara online.

Penguatan hubungan antara guru dan orang tua siswa perlu ditingkatkan agar secara bersama-sama dapat memantau perkembangan peserta didik atau siswa, bahkan jika perlu, dibuatkan juga grup whatsapp orang tua murid agar dapat terjalinnya kerjasama antara tiap orang tua siswa dan juga guru. 


\section{REFERENSI}

Amal, B. K. (2019). Pembelajaran Blended learning Melalui Whatsapp Group (Wag). Prosiding Seminar Nasional Fakultas Ilmu Sosial Universitas Negeri Medan, 3, 700-702. http://semnasfis.unimed.ac.id/wpcontent/uploads/2019/11/06.Bakhrul.pdf

Ariawan, S., Aji, A. B., \& Tawil, T. (2021). Pengaruh Blended learning Flex Model Berbantuan Media Video Terhadap Hasil Belajar IPA Materi Ekosistem. Borobudur Educational Review, 1(01), 44-56. https://doi.org/10.31603/bedr.4848

Bersin, J. (2010). REVIEW: The Blended learning Book: Best Practices, Proven Methodologies, And Lessons Learned. Turkish Online Journal of Distance Education, 11(3), 225-228. https://doi.org/10.17718/tojde.15117

Carman, J. M. (2002). Blended learning design: Five key ingredients. Learning, $\quad 11$ (October), 2007. https://doi.org/10.1109/CSSE.2008.1 98

Damayanti, A. (2019). Pembelajaran Jarak Jauh Pada Mata Pelajaran Pendidikan Agama Islam di SMAN 1 Gambut.

Hidayat, I., Hasanah A, N., \& Rahma, M.

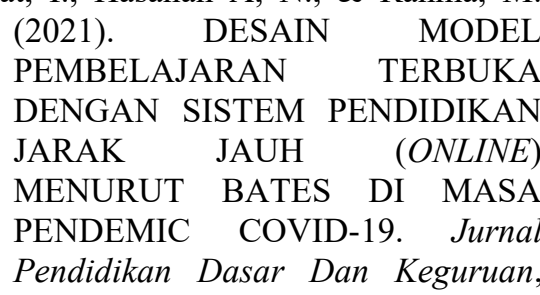
6(1), 24-30. https://doi.org/10.47435/jpdk.v6i1.59 3

Undang-Undang Indonesia Nomor 20 Tahun 2003 Tentang Sistem Pendidikan Nasional, Presiden Republik Indonesia (2003).

Rachmah, H. (2019). BLENDED LEARNING: MEMUDAHKAN ATAU MENYULITKAN? In Prosiding Seminar Nasional Fakultas Ilmu Sosial Universitas Negeri Medan (Vol. 3). http://semnasfis.unimed.ac.id/wpcontent/uploads/2019/11/01.-HuriahRachmah.pdf

Suradika, A., Winata, W., Wicaksono, D., Hadi, M. S., \& Rifqiyati. (2020). The Influence of Instructional Materials and Educational Background on the Learning Outcomes of Islamic Education. Solid State Technology, 63(6), 1027-1043. http://solidstatetechnology.us/index.p $\mathrm{hp} / \mathrm{JSST} /$ article/view/2185

Syarif, I. (2013). Pengaruh model blended learning terhadap motivasi dan prestasi belajar siswa SMK. Jurnal Pendidikan Vokasi, 2(2). https://doi.org/10.21831/jpv.v2i2.103 4

Tucker, C. R. (2012). Blended learning in Grades 4-12. Corwin Press.

Warsita, B. (2007). Peranan Teknologi Informasi dan Komunikasi dalam Penyelanggaraan Pendidikan Jarak Jauh. TEKNODIK, 9-41. https://core.ac.uk/download/pdf/2271 61859.pdf\#page $=9$ 